\title{
Response Time of AAC Graphic Symbol Size and Number in Typically Developing Children
}

\author{
Seoa Hong, Seok Jeong Yeon \\ Program of Speech Language Pathology, Graduate School of Education, Inha University, Incheon, Korea
}

Correspondence: Seok Jeong Yeon Graduate School of Education, Inha University, 100 Inha-ro, Michuhol-gu, Incheon 22212, Korea Tel: +82-32-860-7866

Fax: +82-32-865-8624

E-mail: stonewell@inha.ac.kr

Received: January 5, 2021

Revised: February 9, 2021

Accepted: February 17, 2021

This work is based on the Master's thesis of the first author.

This work was supported by Inha University Research Grant.

\begin{abstract}
Objectives: AAC is a multimodal communication system that augments and provides alternates for individuals with limited verbal skills. It helps people with complex communication needs to communicate effectively with various people, promotes participation in many activities, and further promotes independent life. The purpose of this study was to investigate the response time of the selection of graphic symbols according to the size and number of graphic symbols in 5 and 6 year old typically developing children, to compare the differences, and to find out the correlation between age, vocabulary ability, intelligence, and response time. Methods: The participants were 16 children aged 5 years old, and 17 children aged 6 years. Five AAC boards were developed according to the size and number of graphic symbols. A two-way mixed ANOVA was conducted to find the difference in response time between groups according to AAC board type; and the correlation between age, vocabulary ability, non-verbal intelligence and graphic symbol selection response time was examined. Results: The main effect of the response time for selecting graphic symbols between the 5 and 6 year old groups was significant, and the difference in response time was also significant in the AAC board type according to the size and number of graphic symbols. It was found that age, receptive vocabulary ability, and non-verbal intelligence showed significant correlation according to the size and number of picture symbols. Conclusion: The results of this study show that age, receptive vocabulary ability, and non-verbal intelligence should be considered in selecting the size and number of graphic symbols. The necessity of developing and providing communication boards according to age, vocabulary ability and intelligence of AAC users was discussed.
\end{abstract}

Keywords: Augmentative and alternative communication, Graphic symbols, Size and number, Response time
보완대체 의사소통(augmentative and alternative communication, $\mathrm{AAC}$ )은 일시적 또는 영구적으로 구어(verbal) 능력이 제한된 의사소통장애인이 그들의 제한된 구어능력을 보완하거나 대체할 목적으로 사용되는 체계이다(ASHA, 2005). 개인이 가지고 있는 인 지능력, 언어능력, 운동능력의 개인내 차이로 인해 복합적인 의사소 통 요구가 있는 의사소통장애 아동(children with complex communication needs, 이하 복합 의사소통장애 아동)은 AAC 체계를 통해 다양한 사람들과 효율적인 의사소통을 할 수 있게 되고, 많은 활동 에 참여가 촉진되어 의사소통 기회의 확장으로 더 나은 의사소통 기 술을 발전시킬 수 있게 된다(Beukelman \& Light, 2020).
이러한 $\mathrm{AAC}$ 체계의 긍정적인 측면에도 불구하고, 전문가나 가 족들의 $\mathrm{AAC}$ 체계에 대한 부정적인 인식과 $\mathrm{AAC}$ 시스템 자체의 제 한된 기능의 기회장벽(opportunity barriers)으로 인해 교육 및 언 어재활 현장에서 $\mathrm{AAC}$ 체계를 적용하는데 많은 어려움이 있다 (Kim, Park, \& Kim, 2010). 특히 AAC 사용자의 능력을 고려하지 않은 $\mathrm{AAC}$ 체계 개발과 적용은 복합 의사소통장애 아동이 $\mathrm{AAC}$ 체계를 거부하는 부정적인 결과를 초래하고 이는 의사소통의 실패 와 좌절로 연결된다고 하였다(Beukelman \& Light, 2020). 따라서 $\mathrm{AAC}$ 사용자의 능력에 최적화된 맞춤형 $\mathrm{AAC}$ 체계 구성은 $\mathrm{AAC}$ 체 계 적용을 위한 가장 중요한 첫 단계라고 할 수 있다. 
사용자 맞춤형 AAC 체계 개발을 위해서는 사용자의 능력 평가 가 선행되어야 한다. 여기서 사용자의 능력이란 언어능력, 인지능력, 상징능력, 자세를 포함하는 운동능력, 시청각의 감각능력을 말하 며, 이러한 능력은 $\mathrm{AAC}$ 체계 사용하는데 직간접적으로 영향을 미 치는 요인이다(Park, 2000). 이 가운데 AAC 상징능력 평가에서는 사용자의 능력에 맞는 상징체계의 유형(예, 실제사물, 모형사물, 그 림, 사진 등)을 찾고, 한 화면에 제시되는 적절한 그림상징의 크기와 수를 결정하며, 효과적인 상징 배열과 상징의 범주화 등을 결정해야 한다(Bruno, 2010; Bruno \& Trembath, 2006). 여기서 그림상징의 크 기와 수는 $\mathrm{AAC}$ 사용자가 표현하고자 하는 메시지를 수용이 가능 한 반응시간 내 정확하게 선택하는 능력을 기준으로 결정해야 한다.

$\mathrm{AAC}$ 그림상징체계에 대한 연구는 그림상징 자체의 특성을 밝히 고자 하는 연구를 중심으로 이루어졌다. 먼저 의미유형에 따른 그 림상징 식별의 연구를 살펴보면, 사물을 표상하는 그림상징이 동 작이나 상태를 표상하는 그림상징보다 의미를 연상하는 투명도가 높아 그림상징 선택 정확도가 높은 것으로 나타났다(Yeon, Kim, \& Park, 2016). Shin, Kim과 Park (2017)의 연구에서는 의미유형에 따 른 상징을 판별하는 반응시간을 비교하였는데 명사에 해당하는 그 림상징의 판별 반응속도가 부사나 동사를 판별할 때보다 더 짧은 시간이 소요되는 것으로 나타났다. 이후 동작과 상태를 표상하는 그림상징의 투명성을 높이기 위한 연구들이 수행되었는데 가장 관 심을 둔 요인은 동적화(animation)이다. Choi와 Song (2010a)의 연 구에서는 그림상징의 동적화로 상징에 대한 선택 속도를 향상시킬 수 있다고 하였고, Kang, Lim과 Lee (2018) 연구에서는 동적 상징 이 상징을 인식하는데 효과적이고 정확성이 높다고 하였다. 선행연 구를 종합해보면 의미유형과 동적화 여부에 따라 그림상징의 선택 정확도가 달라지며 선택의 반응속도에도 영향을 미칠 수 있다는 것을 시사하였다.

인지능력에 따른 그림상징 선택의 특징에 대한 연구에 의하면 (Song \& Choi, 2012) 사회적 경험 및 지능이 높을수록 오류율이 낮 은 것으로 확인되었다. Lee, Lee, Kim과 Yeon (2015)은 지적장애 아 동을 대상으로 배열 및 공간 배열에 따른 어휘 경로 유형에 대해 정 확도와 선호도 평가를 실시하였는데, $\mathrm{AAC}$ 사용자 인지능력을 고 려하여 어휘 선택 경로를 제시해야 한다고 강조하였다. 또한 Shin (2017)은 고정배열 조건이 비고정배열 조건에 비해 평균 반응시간 이 유의미하게 짧아 이는 고정배열이 효과적인 의사소통에 긍정적 인 영향을 준다는 것을 확인하였으며, 이는 그림상징의 배열을 고 려한 $\mathrm{AAC}$ 체계 적용은 $\mathrm{AAC}$ 사용자의 사회참여 증진으로 연결된 다고 하였다. 결과적으로 상징체계에 대한 반응시간과 정확도를 촉 진할 때 배열에서 상징이 얼마나 쉽게 발견되는지가 가장 중요한 결
정요인이 된다(Wilkinson, Carlin, \& Jagaroo, 2006). 즉, 이러한 요 인은 $\mathrm{AAC}$ 사용자에게 상징의 판별, 그리고 상징 사용에 영향을 미 친다는 것을 다시 한 번 확인할 수 있었다.

Choi와 Song (2010a)은 도구적 상징을 사용하는 AAC 체계의 의 사전달 속도에 관해 $\mathrm{AAC}$ 사용자들은 의사소통이 효율적이지 못 하고 메시지 전달 타이밍의 제한 속에 의사소통 어려움을 직면한다 고 하였다. AAC 사용자들의 메시지 전달 속도향상을 위해서는 그 림상징의 빠른 판별능력이 필요하며 또한 $\mathrm{AAC}$ 체계에서 애니메이 션 상징을 제시하는 것이 도움이 될 것이라고 제시하였다.

$\mathrm{AAC}$ 그림상징 이해 발달에 대한 연구를 살펴보면, $\mathrm{AAC}$ 그림상 징 이해 발달은 3세 이후에 그림이 사물을 표상할 수 있다는 것을 이해하기 시작한다고 하였다(Beukelman \& Light, 2020). 즉, 3세 이후에 그림상징이 표상하는 의미를 이해하고 사용할 수 있다는 것을 의미한다. $\mathrm{AAC}$ 사용자의 어휘 능력은 $\mathrm{AAC}$ 그림상징을 이해 하고 사용하는데 있어서 메시지 전달의 정확도에 영향을 준다. Lee, Park, Kim과 Park (2004)은 유아기에는 전반적으로 어휘력이 큰 폭 으로 성장하지만 4 세, 5 세, 6 세 각 연령별 차이가 선명하다고 설명 했다. 이후로도 취학 후, 청소년기를 거쳐 어휘발달은 지속적으로 이루어지지만 어휘폭발기 이후는 연령 증가와함께 언어 기술을 정 제해 나가는 것이라고 설명하였다. 표현어휘는 아동이 언어발달 과 정 속 의사소통에 있어서 가장 기초 능력인 수용어휘를 통해서 발 달한다. 다시 말해, 말의 의미를 이해하고, 통사론이 발달하고, 구 어적 표현으로 발달하는 것이므로 수용어휘능력의 발달이 제한적 이라면 의사전달이 어렵다고 설명할 수 있다. 이렇게 영유아기의 수 용어휘 발달이 전반적인 언어발달에 영향을 줄 수 있고, $\mathrm{AAC}$ 그림 상징을 선택하고 수행하는데 있어서도 중요한 영향을 미친다고 할 수 있다. Lee 등(2015) 연구에서 AAC 그림상징 사용에 있어 연령의 영향이 크다는 점을 지적한바 있다.

언어재활사는 $\mathrm{AAC}$ 사용자의 개별적인 특성을 고려하여, 신속 하고 효과적으로 의사소통 표현을 할 수 있도록 지원해야한다 (Kim, 2014), 앞서 언급한 바와 같이 선행연구를 통해 AAC의 반응 시간이나 정확도는 그림상징의 색, 도상성, 인식, 선호도, 투명성, 품 사, 배열과 수, 크기 등 다양한 요인에 대해 복합적인 영향을 받는다 는 것을 알 수 있다. 그러므로 이러한 변수들을 고려하여 $\mathrm{AAC}$ 그림 상징체계에 특성을 확인하고, $\mathrm{AAC}$ 사용자들에게 최적화된 기준 을 적용할 필요성이 있다. AAC 그림상징을 통한 의사소통의 질을 낮추는 요인 중 하나는 복잡한 메시지 선택으로 인한 적절한 타이 밍을 놓치는 것이다. AAC 체계를 통한 의사소통 상황에서 메시지 전달이 느린 경우, 상대방과의 의사소통 상황에서 얻는 정보의 양 과 질에 영향을 미치고, 이는 의사소통의 실패로 연결되기 때문에 
복합 의사소통장애 아동의 능력에 맞는 그림상징의 크기와 수 선 정은 매우 중요하다.

$\mathrm{AAC}$ 사용자는 상대방과 의사소통하기 위해서 전달하고자 하 는 메시지를 기억하고, $\mathrm{AAC}$ 보드에서 그 메시지의 그림상징을 확 인, 식별하고 선택하는 일련의 과정을 수행해야 한다. 또한 이러한 과정이 성공적인 의사소통으로 연결되기 위해서는 사회적으로 수 용이 가능한 적절한 시간 내에 이루어져야 한다. 그러나 앞서 설명 한 AAC 그림상징 수행 관련 연구들은 $\mathrm{AAC}$ 그림상징 개발이나 선 택의 정확도에 초점을 두고 있어 어떠한 그림상징이 더 식별하기 쉬 운지, 정확한 그림상징을 선택하기 위해서는 어떠한 점을 고려해야 하는지, 그림상징을 선택하는데 언어와 문화가 어떠한 영향을 미치 는지를 중심으로 연구가 이루어졌다(Choi \& Song, 2010a, 2010b; Kang, Kim, \& Yeon, 2019; Shin et al., 2017; Yeon et al., 2016). 현재 타당성이 검증된 한국형 AAC 상징체계가 개발(Chae, Park, Kim, \& Yeon, 2020; Park, et al., 2016)되고 교육 및 재활현장에서 많이 사 용되고 있는 이 시점에서 $\mathrm{AAC}$ 그림상징 수행능력을 속도와 사용 자 개인 변인으로 확장하여 살펴볼 필요가 있다. 특히 $\mathrm{AAC}$ 그림상 징 선택 반응속도 관련하여 연령이나 AAC 보드에 따른 명확한 기 준이나 정보가 제시된 연구가 매우 제한적인 상황에서 일반 아동 을 대상으로 한 기초연구가 우선적으로 이루어져야 한다.

따라서, 본 연구에서는 $\mathrm{AAC}$ 체계 구성을 위한 경험적 근거기반 정보 제공을 위해 5 세와 6 세의 일반아동을 대상으로 그림상징의 크기와 수에 따른 5 가지의 유형의 $\mathrm{AAC}$ 보드를 제작하여, $\mathrm{AAC}$ 보 드 유형에 따른 그림상징 선택 반응속도를 측정하고, 반응속도의 차이를 연령과 $\mathrm{AAC}$ 보드 유형으로 살펴보고자 하였다. 또한 AAC 의사소통능력에 영향을 미치는 내적요인인 연령, 수용어휘능력, 표 현어휘능력, 비언어성 지능이 AAC 보드 유형에 따른 반응속도와 어떠한 상관관계가 있는지 살펴보고자 하였다. 본 연구목적에 따 른 연구문제는 다음과 같다. 첫째, 그림상징의 크기와 수를 달리한 5 개의 $\mathrm{AAC}$ 보드 유형(4판, 8 판, 16 판, 32판, 45 판)과 집단(5세, 6 세) 에 따른 그림상징 선택 반응속도에 유의한 차이가 있는가? 둘째, 연 령, 수용어휘능력, 표현어휘능력, 비언어성 지능과 AAC 보드 유형 별 그림상징 선택 반응속도와의 상관관계는 어떠한가?

\section{연구방법}

\section{연구참여자}

본 연구의 참여자는 인천 및 경기 지역에 거주하는 5 세 일반 아 동 16 명(남아 10 명, 여아 6 명), 6 세의 일반 아동 17 명(남아 10 명, 여 아 7명), 총 33 명이다. 연구참여자 선정 기준으로 1) 아동 보호자 보
Table 1. Participants' information ( $\mathrm{N}=33)$

\begin{tabular}{lcc}
\hline & 5-year-olds ( $\mathrm{N}=16)$ & 6-year-olds ( $\mathrm{N}=17)$ \\
\hline Chronological age (mo) & $65.31(3.67)$ & $78.65(3.10)$ \\
Nonverbal IQ (raw score) & $105.31(8.06)$ & $113.65(9.48)$ \\
REVT-R (raw score) & $65.31(7.26)$ & $73.41(9.66)$ \\
REVT-E (raw score) & $72.00(10.53)$ & $79.41(10.71)$ \\
\hline
\end{tabular}

Values are presented as mean (SD).

Nonverbal I0 was measured with Korean Comprehensive Test of Nonverbal Intelligence-Second Edition (K-CTONI-II; Park, 2014).

REVT-E = Expressive Vocabulary Test (Kim et al., 2009); REVT-R=Receptive Vocabulary Test (Kim et al., 2009).

고에 의해 신체, 운동, 청각, 시각에 문제가 없으며, 2) 수용·표현 어 휘력 검사(REVT; Kim, Hong, Kim, Jang, \& Lee, 2009) 결과 -2 SD 이상이며, 3) 한국 비언어 지능검사(K-CTONI-II; Park, 2014)결과 지능지수 85 이상이고, 4) 본 연구에서 제시되는 AAC 그림상징의 목표어휘를 모두 이해하는 아동으로 하였다. 언어재활 기관에 모 집 공고를 통해 자발적으로 연구참여에 동의한 아동을 대상으로 본 연구를 실시하였으며, 5 세 집단의 평균 연령은 $5 ; 4$ 세이며, 6 세 집 단의 평균 연령은 6;5세이다. 연구참여자의 구체적인 정보는 Table 1 에 제시하였다.

\section{실험과제}

어휘 및 $\mathrm{AAC}$ 그림상징 선정

본 연구에서는 그림상징의 의미 유형에 따른 선택 정확도의 차이 와(Yeon et al., 2016), 선택 반응시간 차이 연구(Choi \& Song, 2010b; Shin, 2018)를 근거로, 의미유형이 그림상징 선택에 미치는 영향을 최소화하기 위해 본 실험에 사용된 어휘는 일반명사로 제한하였 다. 한국판 맥아더-베이츠 의사소통 발달 평가(K M-B CDI; Pae \& $\mathrm{Kwak}, 2011)$ 에서 제시된 18-30개월의 영아가 $75 \%$ 이상 습득하였다 고 제시된 어휘목록 중 명사 어휘를 선정하였고, 의미간섭을 배제 하기 위해 4 가지(일상생활 사물, 동물, 옷, 음식) 범주에서 총 50개 를 선정하였다. 선정된 어휘의 난이도에 대한 타당도 평가는 언어치 료 경력 10 년 이상의 언어재활사 1 인이 실시하여 모두 5 세 이전에 습득하는 어휘로 난이도의 적절성을 평가받았다. 실험에 사용한 최종목표 어휘목록은 Appendix 1에 제시하였다.

선정된 어휘를 표상하는 그림상징은 한국형 $\mathrm{AAC}$ 상징체계(Park et, 2016; Yeon et al., 2016)에서 선정하여 사용하였다. 한국형 AAC 상징체계(KAAC Symbols)는 우리나라의 고유문화와 언어적 특성 을 고려한 $\mathrm{AAC}$ 그림상징체계로 다양한 장애유형의 특징을 고려한 어휘개념을 선정하여 그래픽 이미지로 개발된 상징체계이다. 특수 교사와 언어재활사 등 $\mathrm{AAC}$ 전문가로부터 상징표현의 타당성이 검 
증된 체계이다(Park et al., 2016; Yeon et al., 2016).

\section{그림상징 크기와 수에 따른 $\mathrm{AAC}$ 보드 제작}

본 연구에서는 그림상징의 선택 반응속도 측정을 위해 격자형 디스플레이를 사용하여 AAC 보드를 제작하였다. 그림상징들을 가로 세로 기준 $2 \times 2$ ( 4 cell), $4 \times 2$ ( 8 cell), $4 \times 4$ (16 cell), $8 \times 4$ (32 cell), $9 \times 5$ ( 45 cell)와 같은 격자 모양으로 그림상징의 크기와 수 배 열을 다르게 제시하였다. 실험과제에서 사용된 AAC 보드는 Microsoft Office Power Point로 제작하여 노트북 15인치 $(37-39 \mathrm{~cm})$ 화면으로, 해상도는 $1,920 \times 1,080(\mathrm{HD})$ 로 제시하였다. $\mathrm{AAC}$ 보드 는 각 유형별로 10 개씩 총 50 개의 문항으로 구성되었으며, 유형별 로 각 그림상징의 노출빈도를 동일하게 제시하고 목표 그림상징의 위치는 격자배열 가운데 무작위로 제시하였다. 이 외에 학습효과 를 방지하기 위해 $\mathrm{AAC}$ 보드판을 참여자에게 무작위로 제시하였 다. 개발된 AAC 보드는 언어병리학 박사학위를 소지한 1 인의 검토 를 거쳐 개발되었다. 실험과제인 그림상징의 수에 따른 $\mathrm{AAC}$ 보드 의 예는 Figures 1-5와 같다.

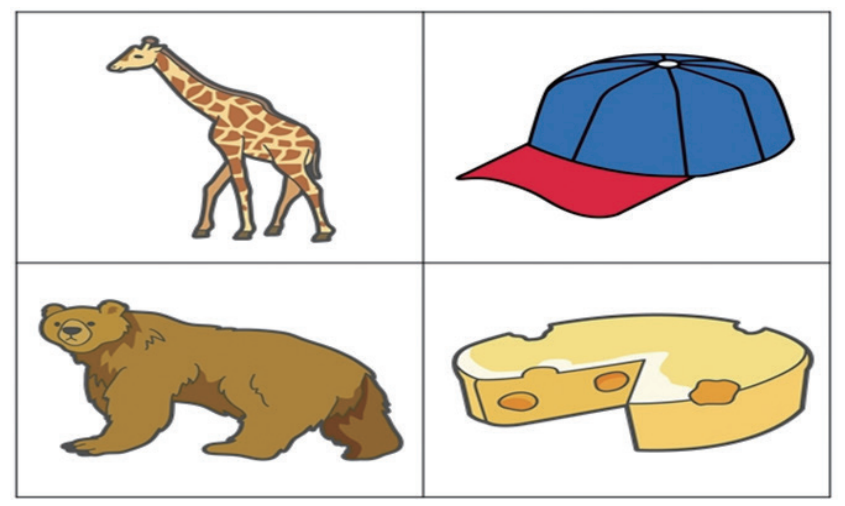

Figure 1. Example of AAC board in 4 cell display.

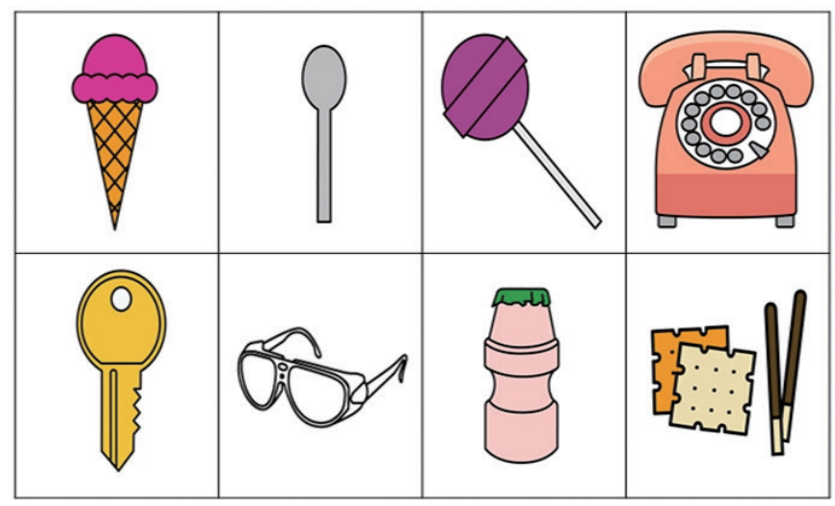

Figure 2. Example of AAC board in 8 cell display.

\section{연구절차}

본 실험은 2020년 1월 2일부터 3월 15일까지 진행되었다. 연구참여 자의 보호자와 사전에 정한 시간에 연구참여자의 집 또는 연구참여 자의 형제나 자매가 다니고 있는 치료센터의 조용하고 독립된 공간 에서 개별적으로 진행되었다. 연구참여자 선정을 위한 기본 검사(예, REVT, K-CTONIC-II)와 실험과제는 아동의 주의집중 시간을 고려

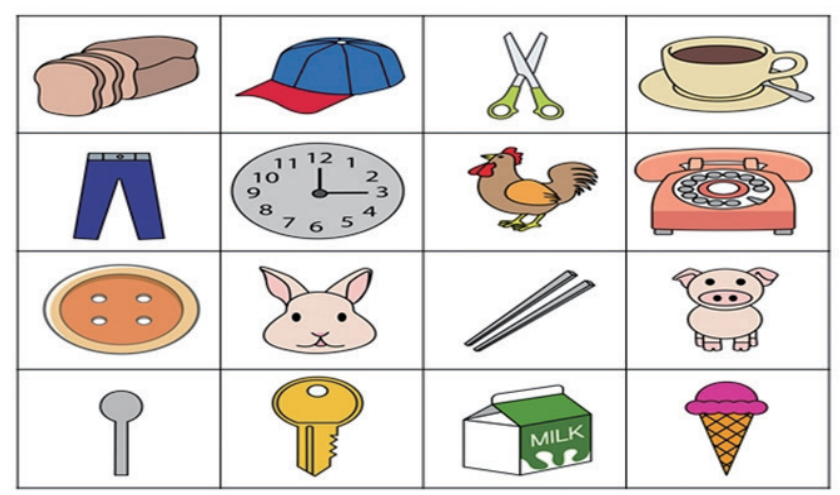

Figure 3. Example of AAC board in 16 cell display.

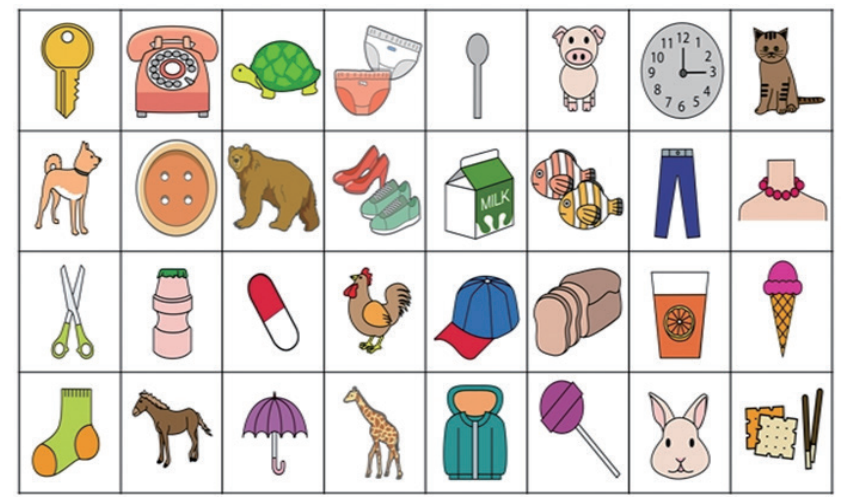

Figure 4. Example of AAC board in 32 cell display.

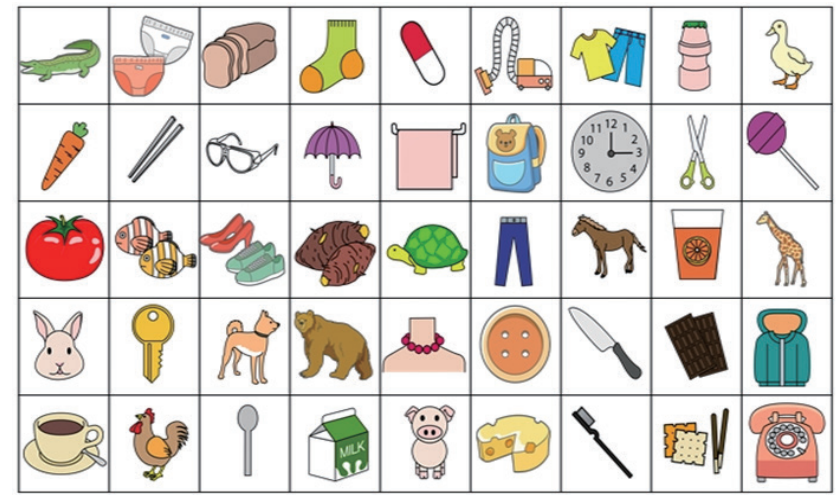

Figure 5. Example of AAC board in 32 cell display. 
하여 2 회기로 나누어 실시하였다. 기본 검사 실시 후 1 주 이내에 실험 과제를 실시하였으며, 모두 동일한장소에서 실시하였다.

본 실험과제를 실시하기 전에 3 개의 연습 문항을 실시하여 검사실 시 방법을 학습하게 하였다. 검사자는 아동에게 “지금부터 선생님이 말하는 낱말의 그림을 화면에서 찾아 손가락으로 눌러주세요.”라고 지시하였으며 아동이 목표어휘를 듣고 해당 그림상징을 손가락으로 스크린 화면에 직접 터치하게 하였다. 수행 방법을 충분히 학습하여 참여자가 정확하게 수행하는 것을 확인한 후 본 실험을 실시하였다.

\section{자료측정}

본 연구의 종속변인은 연구참여자의 목표어휘에 대한 $\mathrm{AAC}$ 그림 상징 선택 반응속도이다. 본 연구에서 측정한 반응속도 $(\mathrm{ms})$ 는 1) 정반응 문항만을 분석하였고, 2) 아동이 자발적으로 반응을 수정 하는 경우에는 검사지시 이후 정반응에 이르는 모든 시간을 포함 하여 분석하였다. 본 실험에서 연구참여자는 모든 문항에 정반응 을 보였으며, 자발적으로 답을 수정한 경우는 3 회였다. 실험장면 녹 화는 스마트폰 카메라(iPhone 11) 기능을 사용하여 연구참가자의 손가락이 스크린 화면에 닿는 시점이 잘 보이도록 측면에서 촬영하 였다. 그림상징 선택 반응시간(response time)은 연구자가 목표 단 어를 “ $\bigcirc \bigcirc$ ”라고 들려주었을 때 검사지시 문장의 마지막 음절 이 끝난 시점부터 연구참여자의 손가락이 화면의 목표 그림상징에 터치된 순간까지의 소요된 시간으로 하였으며, 실험장면 녹화영상 을 Adobe-Premiere Pro ver, cc 2020 프로그램을 사용하여 ms (1/100초) 단위로 측정 및 분석하였다. 연구참여자의 반응사진과 자료분석을 위한 분석프로그램의 화면의 예를 Figures 6, 7에 제시 하였다.

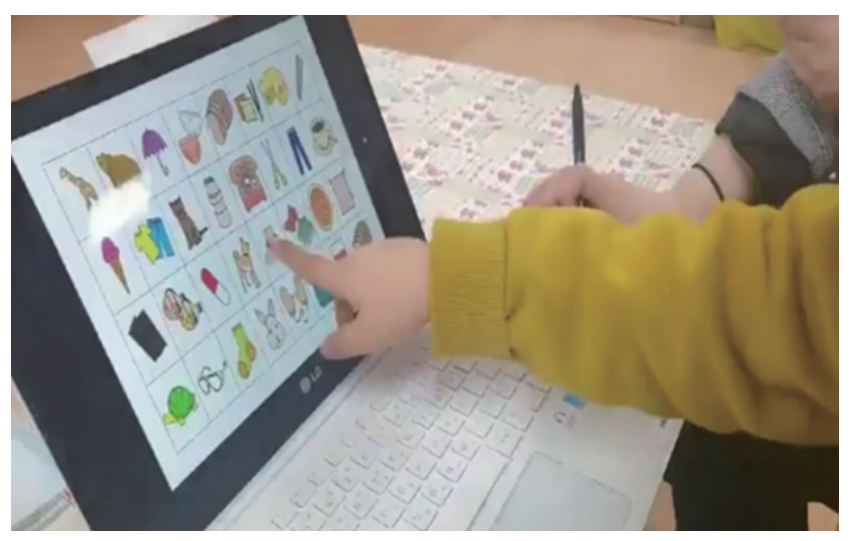

Figure 6. A screenshot of participant's response.

\section{분석자 간 신뢰도}

분석자 간 신뢰도(inter-rater reliability)를 측정하기 위하여 본 연구자 외에 언어치료 경력이 3년 이상이며, 언어치료학 석사과정 을 수료한 언어재활사를 제 2 분석자로 선정하였다. 연구자는 제 2 분 석자에게 반응시간을 측정하는 가이드를 제공하고 Adobe-Premiere Pro ver, cc 2020 프로그램 사용방법을 훈련하였다. 연구참여 자 33 명 중 $20 \%$ 에 해당하는 7명을 무작위로 선정한 후 녹화자료를 통해 반응시간을 독립적으로 측정하고 분석자 간 일치도를 구하였 다. 측정된 반응시간에서 0.01 초차이는 일치하는 것으로 간주하였 다. 분석자 간 신뢰도는 일치한 항목 수와 불일치한 수를 합하여 일 치한 수로 나눈 뒤 100 을 곱하여 산출하였다. 분석자 간 신뢰도 결 과는 $93.71 \%$ 로 나타났다.

\section{통계분석}

그림상징의 크기와 수에 따른 AAC 보드 유형(4판, 8판, 16판, 32 판, 45 판)과 집단(5세, 6 세)의 반응속도 차이 검증을 위해 혼합이원 분산분석(Mixed two-way ANOVA)을 실시하였다. 5세와 6세 집 단이 피험자 간 요인(between subject factors)이며, 그림상징 크기 와 수에 따른 5가지의 AAC 보드유형이 피험자 내 요인(within subject factors)으로 하였다. 연령, 수용어휘능력, 표현어휘능력, 비언어 성 지능 및 $\mathrm{AAC}$ 보드유형 반응속도의 상관관계 분석을 위하여 피 어슨 상관관계 분석(Pearson's correlation analysis)을 실시하였다. 모든 통계분석은 SPSS ver. 23 프로그램을 사용하였다.

\section{연구결과}

\section{그림상징 크기와 수에 따른 AAC 보드 유형의 그림상징 선택 반응속도}

그림상징 크기와 수에 따른 $\mathrm{AAC}$ 보드 유형 간 두 집단(5세, 6세) 의 그림상징 선택 반응속도를 살펴보면, 5 세 집단의 경우 4 판에서

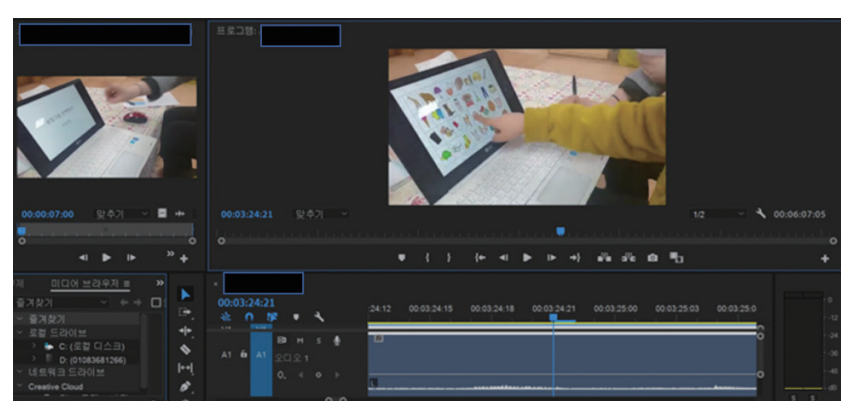

Figure 7. Example of Adobe-Premiere Pro ver, cc 2020. 
평균 $.81 \mathrm{~ms}$ 의 반응속도를 나타냈으며, 8 판에서는 $1.45 \mathrm{~ms}, 16$ 판에 서는 $2.25 \mathrm{~ms}, 32$ 판에서는 $3.84 \mathrm{~ms}, 45$ 판에서는 $5.61 \mathrm{~ms}$ 의 평균 반 응속도를 보이는 것으로 나타났다. 6세 집단은 4판에서 평균 .83 $\mathrm{ms}, 8$ 판에서 $1.10 \mathrm{~ms}, 16$ 판에서 $1.82 \mathrm{~ms}, 32$ 판에서 $3.11 \mathrm{~ms}, 45$ 판에 서 $4.23 \mathrm{~ms}$ 의 평균 반응속도를 보이는 것으로 나타났다. 두 집단 모 두 한 화면에 제시되는 그림상징의 수가 많아질수록 반응속도의 평균이 점차 높아져 느린 반응을 보이는 것으로 나타났다. 이에 대 한 기술통계는 Table 2에 제시하였고 분석결과는 Figure 8과 같다.

$\mathrm{AAC}$ 보드 유형에 따른 집단 간의 주효과와 상호작용 효과의 유 의성 검증을 위해 혼합이원분산분석을 실시하였다. 집단에 따른 반응속도에서 통계적으로 유의한 차이가 있는 것으로 나타났다 $(F=10.472, p<.01)$. 또한 $\mathrm{AAC}$ 보드 유형에 따른 그림상징 선택 속 도의 주효과가 유의 $(F=69.402, p<.001)$ 한 것으로 나타났다. 그러 나 $\mathrm{AAC}$ 보드 유형에 따른 집단 간의 상호작용 효과는 유의하지 않 은 것으로 나타났다 $(p>.05)$.

집단 간 반응속도의 주효과의 유의성에 대하여 사후 분석을 실 시한 결과, 8 판 $(t=2.208, p<.05)$ 과 16 판 $(t=2.082, p<.05), 45$ 판 $(t=2.065, p<.05)$ 에서 집단 간 차이가 유의한 것으로 나타났으나 4

Table 2. Result of response time(ms) in size and numbers of graphic symbols

\begin{tabular}{lcccc}
\hline & 5-year-olds & 6-year-olds & Total & $t$ \\
\hline 4 cell & $.81(.21)$ & $.83(.34)$ & $.82(.28)$ & -0.217 \\
8 cell & $1.45(.42)$ & $1.10(.49)$ & $1.27(.48)$ & $2.208^{*}$ \\
16 cell & $2.25(.59)$ & $1.82(.59)$ & $2.03(.62)$ & $2.082^{*}$ \\
32 cell & $3.84(1.95)$ & $3.11(1.01)$ & $3.47(1.56)$ & 1.358 \\
45 cell & $5.61(1.85)$ & $4.23(1.98)$ & $4.90(2.02)$ & $2.065^{*}$ \\
\hline
\end{tabular}

Values are presented as mean (SD).

${ }^{*} p<.05$.
판과 32판에서는 집단 간 차이가 유의하지 않는 것으로 나타났다 ( $p>.05)$. AAC 보드 유형 간 반응속도 주효과의 유의성에 대한 사 후 분석을 실시한 결과 4 판과 8 판 $(t=-4.562, p<.001), 8$ 판과 16 판 $(t=-5.813, p<.001), 16$ 판과 32 판 $(t=-5.020, p<.001), 32$ 판과 45 판 $(t=-3.204, p<.001)$ 간의 반응속도의 차이가 유의한 것으로 나타 났다. 즉, 그림상징 크기와 수에 따라 그림상징 선택의 반응속도 평 균에 유의한 차이를 보이는 것으로 나타났다.

\section{연령과 그림상징 선택 반응속도와의 상관관계}

5-6세 아동의 AAC 보드 유형에 따른 그림상징 선택 반응속도가 수용어휘능력, 표현어휘능력, 연령, 비언어성 지능과 어떠한 상관관 계가 있는지 알아보기 위해 피어슨 상관분석을 실시하였다(Table 3). 먼저, 연령과 $\mathrm{AAC}$ 보드 반응속도 간에 상관관계를 분석한 결 과, $\mathrm{AAC}$ 보드 16 판과 연령은 비교적 높은 부적 상관관계를 나타내

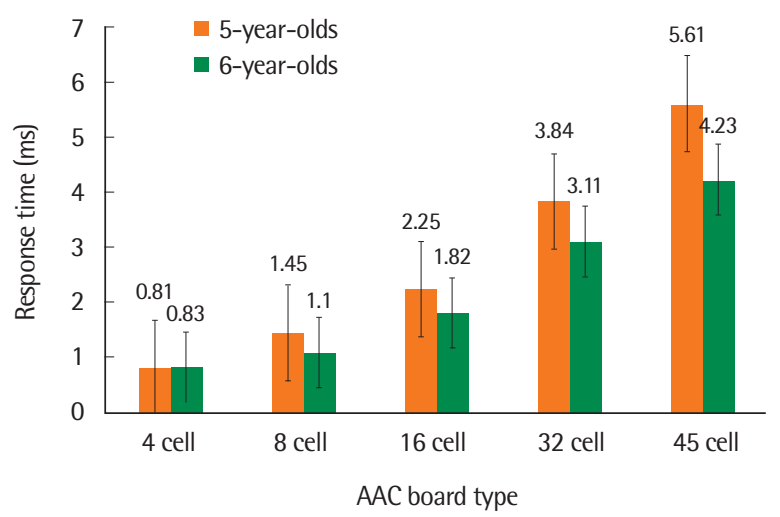

Figure 8. Mean response time in size and number of graphic symbol (Error $\mathrm{Bar}=\mathrm{SD})$

Table 3. Correlations matrix in variables

\begin{tabular}{|c|c|c|c|c|c|c|c|c|}
\hline Measure & 1 & 2 & 3 & 4 & 5 & 6 & 7 & 8 \\
\hline \multicolumn{9}{|l|}{ Age } \\
\hline REVT-R & $.568^{* *}$ & & & & & & & \\
\hline REVT-E & $.375^{*}$ & $.430^{*}$ & & & & & & \\
\hline Nonverbal IO & $.564^{* *}$ & $.425^{*}$ & .138 & & & & & \\
\hline 4 cell & .084 & $.478^{* * *}$ & .100 & .730 & & & & \\
\hline 8 cell & -.341 & -.238 & -.102 & -.210 & -.051 & & & \\
\hline 16 cell & $-.423^{*}$ & -.001 & -.303 & -.178 & $.358^{*}$ & .104 & & \\
\hline 32 cell & -.211 & .062 & -.290 & -.194 & .022 & .045 & .051 & \\
\hline 45 cell & $-.364^{*}$ & $-.410^{*}$ & -.073 & $-.571^{* *}$ & -.150 & $.599^{* *}$ & -.022 & -.018 \\
\hline
\end{tabular}

Nonverbal I0 was measured with Korean Comprehensive Test of Nonverbal Intelligence-Second Edition (K-CTONI-I; Park, 2014). REVT-E=Expressive Vocabulary Test (Kim et al., 2009); REVT-R=Receptive Vocabulary Test (Kim et al., 2009); $1=$ age; $2=$ REVT-R; $3=$ REVT-E; $4=$ Nonverbal IQ; $5=4$ cell; $6=8$ cell; $7=16$ cell; $8=32$ cell. ${ }^{*} p<.05,{ }^{* *} p<.01$. 
어 연령이 높을수록 그림상징 선택 반응속도가 빠른 것으로 나타 났다 $(r=-.423, p<.05)$. 45판과 연령의 상관관계는 유의하게 낮은 부적 상관관계가 있는 것으로 나타났다 $(r=-.364, p<.05)$.

\section{어휘능력과 그림상징 선택 반응속도와의 상관관계}

어휘능력과 그림상징 선택 반응속도와의 상관관계를 분석한 결 과, 수용어휘능력과 4판의 반응속도 간에 통계적으로 유의한 비교 적 높은 정적 상관관계가 있는 것으로 나타났다 $(r=.478, p<.01)$. 즉, 수용어휘점수가 높을수록 $\mathrm{AAC}$ 보드 4판에서 그림상징 선택 반응속도가 느린 것으로 나타났다. 그러나 수용언어능력과 $\mathrm{AAC}$ 보드 45 판의 반응속도에는 통계적으로 유의한 비교적 높은 부적 상관관계가 있는 것으로 나타났다 $(r=-.410, p<.05)$. 즉 수용어휘 능력 점수가 높을수록 그림상징 선택 반응속도가 빠른 것으로 나 타났다. 표현어휘능력은 모든 AAC 보드 유형(4판, 8판, 16판, 32판, 45 판)에서 통계적으로 유의한 상관관계가 나타나지 않았다 $(p>$.05).

\section{비언어성 지능과 그림상징 선택 반응속도와의 상관관계}

비언어성 지능점수와 그림상징 선택 반응속도와의 상관관계를 분석한 결과, $\mathrm{AAC}$ 보드 45 판에서의 반응속도와 비언어성 지능에 서 통계적으로 유의하게 높은 부적 상관관계가 있는 것으로 나타 났다 $(r=-.571, p<.01)$. 즉, 비언어성 지능점수가 높을수록 45판에 서의 반응속도가 빠른 것으로 나타났다. 45 판 이외의 AAC 보드 유 형에서는 유의한 상관관계가 나타나지 않았다 $(p>.05)$.

\section{논의 및 결론}

본 연구는 5-6세 일반아동 33명을 대상으로 그림상징의 크기와 수에 따른 $\mathrm{AAC}$ 보드 유형에서 집단 간 그림상징의 선택 속도 차이 와 연령, 수용어휘능력, 표현어휘능력, 비언어성 지능이 AAC 보드 유형과 어떠한 상관관계가 있는지 살펴보았다. 본 연구결과 $\mathrm{AAC}$ 보드에서 한 화면에 제시되는 그림상징의 수가 많아질수록 목표 그 림상징을 판별하는데 소요시간이 유의하게 길어지며, 집단 간 반 응속도의 차이가 유의한 것으로 나타났다. 또한 연령, 비언어성 지 능, 수용어휘능력이 AAC 보드의 그림상징 선택 반응속도와 유의 한 상관을 보인 요인으로 나타났다. 이러한 연구결과에 따른 논의 및 결론은 다음과같다.

첫째, 두 집단(5세, 6세) 간 반응속도의 차이를 분석한 결과, $\mathrm{AAC}$ 보드 8 판, 16 판, 45 판에서 통계적으로 유의한 차이가 있는 것 으로 나타났으며, 4 판과 32 판에서는 집단 간 차이가 유의하지 않은
것으로 나타났다. 즉, $\mathrm{AAC}$ 보드 8 판, 16 판, 45 판에서 6 세가 5 세보 다 유의하게 빠른 반응속도를 보이는 것으로 나타났으며, 이는 그 림상징의 수와 상징배열 유형에 따른 4 세와 5 세 아동의 반응속도 차이를 연구한 Light 등(2004)의 연구결과와 유사한 결과이다. 이 와 같이 연령에 따른 차이는 어린 연령의 아동이 그 보다 나이가 많 은 아동에 비해 목표 그림상징을 확인하고 처리하는데 더 많은 시 간이 소요되어 연령별 차이가 난다고 하였다(Light et al., 2004). 한 화면에 제시되는 그림상징의 수가 4 개인 경우 그림상징을 식별하고 확인하는데 소요되는 시간이 비교적 짧기 때문에 연령에 따른 발 달에 간섭을 받지 않아 연령에 따른 유의한 차이가 없는 것으로 해 석할 수 있겠다. 그러나 AAC 보드 8판 이상에서 연령에 따라 차이 가 있는 것으로 나타나, 이는 $\mathrm{AAC}$ 보드에서 그림상징을 선택하는 능력이 발달하고 있다는 점을 의미한다고 할 수 있다. 따라서 AAC 보드에 제시되는 그림상징의 수가 8판 이상인 경우에는 발달연령 을 고려하여 그림상징의 개수를 선정해야 하는 점을 시사한다고 할 수 있겠다. 다만, 본 연구에서 32 판에서의 집단 간 차이가 나타나 지 않았는데, 기술적 통계치를 비교하면 4판에서 평균의 차이에 비 해 32 판에서의 평균의 차이가 큰 것으로 보아 차이의 방향성 측면 에서 연령 간 차이를 보인다고 할수 있겠다.

둘째, $\mathrm{AAC}$ 보드 유형에 따른 반응속도 차이를 검증한 결과, 각 각의 $\mathrm{AAC}$ 보드 유형(4판, 8 판, 16 판, 32판, 45 판) 간에 통계적으로 유의한 차이를 보였다. 즉, 그림상징의 수가 증가될수록 그림상징 선택 반응속도의 차이가 유의한 것으로 나타났다. 이는 한 화면에 제시되는 그림상징의 개수가 많아지면 판별하는 처리시간이 더 소 요되기 때문이라는 Light 등(2004)의 연구와도 일치되는 결과라고 할 수 있다. 그림상징의 수가 많아 비목표 상징이 많을수록 상징을 식별하고 처리하는 과정에서 더 복잡한 과정이 요구된다는 것과 맥락을 같이한다고 볼 수 있다. 이는 그림상징의 크기와 수에 따른 배열의 난이도가 높을수록 그림상징 선택 반응시간이 더 길게 소 요되며, $\mathrm{AAC}$ 보드 활용 능력에도 영향을 끼친다고 설명한 선행연 구(Shin, 2018)와 목표 상징을 인식하고 판별할 때 영향을 미친다 는 점에서 유사한 결과라고 할 수 있다. 또한, 그림상징의 수가 더 적 고 배열의 복잡성이 낮을 때 상징을 식별하는데 효율적이라는 선행 연구와도 일치된다고 할 수 있겠다(Mizuko, Reichle, Ratcliff, \& Esser, 1994). 사후 검증으로 실시한 각 집단 내에서 AAC 보드 유형에 따른 반응속도의 차이를 분석한 결과, 두 집단 모두 $\mathrm{AAC}$ 보드 유 형에 따른 반응속도에 유의한 차이가 있는 것으로 나타났다. 즉, 두 집단 모두 그림상징의 수가 많아질수록 느린 반응속도를 보이는 것 으로 나타났다.

셋째, $\mathrm{AAC}$ 보드 유형에 따른 그림상징 선택 반응속도와 관련 변 
인과의 상관관계를 분석한 결과, 연령은 16 판과 45 판에서 유의한 부적 상관관계가 있는 것으로 나타났다. 이와 같이 본 연구의 그림 상징 인식 능력이 연령이 증가함에 따라 발달하여 상징유형을 더 잘 이해하는 것으로 나타났다는 선행연구(Lee \& Park, 2016; Worah, McNaughton, Light, \& Benedek-Wood, 2015)의 결과와 유사 한 결과라고 해석할 수 있겠다. 연령과의 상관관계에서는 그림상징 인식 능력이 연령이 증가함에 따라 발달하여 상징유형을 더 잘 이 해하는 것으로 나타나 선행연구(Lee \& Park, 2016; Worah et al., 2015)와도 일치하였다

수용어휘능력은 4 판과는 유의한 정적 상관관계를 보였으나 45 판에서 유의한 부정 상관관계가 있는 것으로 나타났다. 표현어휘능 력은 AAC 보드 유형에 따른 반응속도와 유의한 상관관계가 나타 나지 않았다. 이는 수용어휘능력이 높을수록 4판에서 그림상징 선 택에 대해 신중하게 반응했을 가능성이 있으며, 반면, 45 판과 같이 그림상징의 수가 많은 $\mathrm{AAC}$ 보드에서는 수용어휘능력이 좋을수록 반응속도가 빠르다는 결과가 나타났다. 표현어휘능력과 AAC 보 드 유형 간 반응속도에는 유의한 상관관계가 없는 것으로 나타났는 데, 이를 $\mathrm{AAC}$ 체계가 구어능력이 제한된 의사소통장애아동이 시 각자극을 사용하여 의사소통하는 체계로, 목표어휘에 대한 이해 와 그림상징 선택의 관계가 표현어휘능력보다는 수용어휘능력과 관계가 있다고 해석할 수 있겠다. 즉, 그림상징의 수가 많아질수록 그림상징 선택의 반응은 수용어휘능력과 밀접한 관련이 있는 것으 로 $\mathrm{AAC}$ 보드에서 그림상징의 개수를 확장하기 위해서 참여자의 수 용어휘능력이 뒷받침되어야한다는 점을 의미한다고 할 수 있겠다.

비언어성 지능과 $\mathrm{AAC}$ 보드 45 판 간에 높은 상관관계가 나타났 다. 그림상징이 많고 복잡한 $\mathrm{AAC}$ 보드가 제시되었을 때 비언어성 지능이 높을수록 그림상징을 식별하고 선택하기에 용이하여 더 빨 리 목표 상징을 찾아낸다는 것을 의미한다. 지능지수가 높을수록 상징에 대한 오류율이 적다는 Song과 Choi (2012)의 선행연구와도 유사한 결과라고 할 수 있다. 본 상관관계 분석을 통해 수용어휘능 력과 비언어성 지능이 $\mathrm{AAC}$ 보드 45판에서 그림상징의 식별 및 선 택에 상관이 높은 요인인 것을 알 수 있었다. 따라서 $\mathrm{AAC}$ 보드 구 성에 있어서 그림상징의 크기와 수 선정은 연령, 수용어휘능력, 비 언어성 지능의 요인을 고려하여 제작하여야 한다는 점을 시사한다 고할 수있겠다.

그림상징의 수가 많아지면 반응속도가 늦어지는 경향은 일반적 으로 예측할 수 있는 사실이나, 현재 사용자의 능력에 따라 AAC 보드를 제작하는데 있어서는 그 근거나 기준이 명확한 연구의 근거 가 부족한 상태이다. 그림상징의 선택의 속도는 의사소통의 반응시 간, 대화주고 받는 시간과도 연관되기 때문에 그림상징을 정확하게
선택하였다고 하더라도 선택의 반응속도가 느리면 의사소통이 실 패하게 된다. 따라서 본 연구는 사용자 맞춤형 $\mathrm{AAC}$ 체계 제작을 위한 일반 아동의 수행 자료를 근거로 $\mathrm{AAC}$ 사용자에게 최적화된 그림상징의 크기와 수를 결정하는데 기초적인 정보를 제공한다는 점에서 의미가 있으며, 언어재활 현장에서 $\mathrm{AAC}$ 사용자 특성, 즉 개 인의 수용어휘능력, 비언어성 지능, 연령을 고려한 $\mathrm{AAC}$ 보드 제작 의 중요성을 강조할 수 있다는 점에는 본 연구의 의의가 있다고 할 수 있겠다.

이와 같은 본 연구의 시사점에도 불구하고 제한점은 다음과 같다. 첫째, 반응속도의 측정을 녹화된 동영상으로 분석했다는 점이다. 후 속 연구에서는 속도 측정을 위한 별도의 터치스크린 기기를 사용하 여 정확한 시간 측정을 통해 오차를 줄인 결과값을 도출하는 보완 이 필요할 것이다. 둘째, $\mathrm{AAC}$ 체계는 대화 상대방과 의사소통 상황 에서 사용되는 체계이다. 본 연구에서 실시한 실험과제는 목표 낱 말을 듣고 반응하는 상황을 사용하였다. 따라서 실제의 대화 맥락 에서 이루어지는 대화의 반응속도로 일반화하여 해석하는 데는 제한이 있다고 할 수 있겠다. 후속 연구에서는 자연스러운 대화 문 맥에서 $\mathrm{AAC}$ 사용자의 상징선택 반응속도를 살펴본다면 $\mathrm{AAC}$ 적 용의 효과를 살피거나 중재 방향성을 결정하는데 더 실제적인 정 보를 제공할 수 있을 것이다. 셋째, 연구참여자의 연령을 5-6세로 제한하고, 고빈도 명사 어휘만을 선정하였기에 다양한 연령대와 명 사 이외의 동사나 형용사의 그림상징으로 일반화하여 해석하는데 제한이 있다. 따라서 학령기와 성인으로 연령을 확대하고, 명사 이 외의 다양한 의미유형의 그림상징으로 확대한 연구가 이루어진다 면, 전 생애기에 따른 AAC 사용자의 의사소통 지원에 시사하는 정 보를 도출할 수 있을 것이다.

\section{REFERENCES}

American Speech-Language-Hearing Association. (2005). Roles and responsibilities of speech-language pathologists with respect to augmentative and alternative communication: position statement [Position Statement]. Retrieved from www.asha.org/policy.

Beukelman, D., \& Light, J. C. (2020). Augmentative \& alternative communication: supporting children and adults with complex communication needs. Baltimore: Paul H. Brookes Publishing.

Bruno, J. (2010). Test of aided-communication symbol performance. Pittsburgh, PA: Dynavox Mayer Johnson.

Bruno, J., \& Trembath, D. (2006). Use of aided language stimulation to improve syntactic performance during a weeklong intervention program. 
Augmentative and Alternative Communication, 22(4), 300-313.

Chae, S., Park, K. O., Kim, K. Y., \& Yeon, S. J. (2020). Development of AAC vocabulary and graphic symbols for Korean people with severe and nonverbal disabilities: focusing on human rights, damage, and community communication. Korean Journal of Physical, Multiple and Health Disabilities, 63(2), 119-140.

Choi, Y. G., \& Song, K. B. (2010a). A study on the effects of animation the identification of emotional graphic symbols. Journal of Speech-Language \& Hearing Disorders, 19(2), 163-178.

Choi, Y. G., \& Song, K. B. (2010b). The effects of realism, color, and type of content on identification of graphic symbol. The Journal of Special Education: Theory and Practice, 11(2), 387-399.

Kang, R. W., Kim, Y. T., \& Yeon, S. J. (2019). Cultural differences on the recognition of social word AAC graphic symbols between Korean and American undergraduate students. Communication Sciences \& Disorders, 24(1), 71-86.

Kang, M. J., Lim, K. Y., \& Lee, H. J. (2018). Accuracy and preference of symbol selection according to emotional vocabulary symbol type. Journal of Speech-Language \& Hearing Disorders, 27(4), 55-60.

Kim, J. Y., Park, E. H., \& Kim, K. Y. (2010). Preliminary study regarding voice output communication content and system development. The Journal of Special Education: Theory and Practice, 11(4), 345-374.

Kim, Y. T. (2014). Using AAC for children with speech-language disorders. AAC Research \& Practice, 2(1), 1-22.

Kim, Y. T., Hong, G. H., Kim, K. H., Jang, H. S., \& Lee, J. Y. (2009). Receptive and Expressive Vocabulary Test (REVT). Seoul: Seoul Community Rehabilitation Center.

Lee, K. S., Park, C. I., Kim, H. H., \& Park, E. S. (2004). Development of generative naming ability in 3, 4, 5, and 6-year-old children. Korean Journal of Communication \& Disorders, 9(3), 1-21.

Lee, H. J., \& Park, H. J. (2016). Conceptual understanding and preference of preschool-aged children according to type of graphic symbols. Communication Sciences \& Disorders, 4(1), 65-82.

Lee, Y. G., Lee, H. J., Kim, Y. T., \& Yeon, S. J. (2015). The performance of Korean children with intellectual disabilities on dynamic AAC technologies with different language organizations. Communication Sciences \& Disorders, $20(2), 344-353$.
Light, J., Drager, K., McCarthy, J., Mellott, S., Millar, D., Parrish, C., \& Welliver, M. (2004). Performance of typically developing four-and five-year-old children with AAC systems using different language organization techniques. Augmentative and Alternative Communication, 20(2), 63-88.

Mizuko, M., Reichle, J., Ratcliff, A., \& Esser, J. (1994). Effects of selection techniques and array sizes on short-term visual memory. Augmentative and Alternative Communication, 10(4), 237-244.

Pae, S. Y., \& Kwak, G. J. (2011). MacArthur-Bates communicative development inventories (KM-B CDI). Seoul: Mindpress.

Park, E. H. (2000). Issues in language development of augmentative and alternative communication users. Korean Journal of Communication \& Disorders, 5(1), 5-32.

Park, H. (2014). Korean version of Comprehensive Test of Nonverbal Intelligence Second Edition (K-CTONI-2). Seoul: Mindpress.

Park, E. H., Kim, Y. T., Hong, K. H., Yeon, S. J., Kim, K. Y., \& Lim, J. H. (2016). Development of Korean Ewha-AAC Symbols: validity of vocabulary and graphic symbols. AAC Research \& Practice, 4(2), 19-40.

Shin, S. E. (2018) The relationship between verification and selection performance on AAC graphic symbols. AAC Research \& Practice, 6(2), 45-61.

Shin, S. E. (2017). Effect of fixed array AAC graphic symbols on sentence construction. Communication Sciences \& Disorders, 22(2), 341-351.

Shin, S. E., Kim, Y. T., \& Park, E. H. (2017). A study on the verification of AAC graphic symbols focusing on nouns, adverbs, and verbs. Communication Sciences \& Disorders, 22(3), 597-607.

Song, K. B., \& Choi, Y. G. (2012). The effect of animation of action symbol for adults, children, and intellectual disabilities. Journal of Intellectual Disabilities, 14(4), 293-310.

Wilkinson, K. M., Carlin, M., \& Jagaroo, V. (2006). Preschoolers' speed of locating a target symbol under different color conditions. Augmentative and Alternative Communication, 22(2), 123-133.

Worah, S., McNaughton, D., Light, J., \& Benedek-Wood, E. (2015). A comparison of two approaches for representing AAC vocabulary for young children. International Journal of Speech-Language Pathology, 17(5), 460469.

Yeon, S. J., Kim, Y. T., \& Park, E. H. (2016). Transparency and name agreement of Korean Ewha-AAC symbols: Nouns, verbs, and adjectives. AAC Research \& Practice, 4(1), 45-63. 
Appendix 1. 본 실험에 사용한 어휘 목록

\begin{tabular}{rcccc}
\hline & 일상생활 & 동물 & 의류 & 음식 \\
\hline 1 & 가위 & 곰 & 모자 & 과자 \\
2 & 수건 & 토끼 & 바지 & 빵 \\
3 & 숟가락 & 개 & 신발 & 사탕 \\
4 & 젓가락 & 거북이 & 단추 & 우유 \\
5 & 시계 & 고양이 & 목걸이 & 아이스크림 \\
6 & 안경 & 기린 & 양말 & 요구르트 \\
7 & 약 & 닭 & 옷 & 주스 \\
8 & 열쇠 & 돼지 & 잠바 & 초콜릿 \\
9 & 우산 & 말 & 장갑 & 치즈 \\
10 & 전화 & 물고기 & 팬티 & 커피 \\
11 & 칼 & 악어 & 가방 & 고구마 \\
12 & 청소기 & 코끼리 & & 당근 \\
13 & 칫솔 & 오리 & & 토마토 \\
\hline
\end{tabular}




\section{국문초록}

\section{$\mathrm{AAC}$ 그림상징 크기와 수에 따른 일반 아동의 반응속도 특성}

홍서아 · 연석정

인하대학교 교육대학원

배경 및 목적: $\mathrm{AAC}$ 체계는 제한된 구어능력을 보완하고 대체하는 체계로 복합 의사소통장애인이 다양한 사람들과 효율적인 의사소 통을 하게 하고, 많은 활동에 참여를 촉진하고 나아가 독립적인 삶을 촉진할 수 있다. 본 연구는 5세와 6세 일반 아동을 대상으로 그림 상징의 크기와 수에 따른 그림상징 선택 반응속도를 측정하여 그 차이를 비교하고, 연령, 어휘능력, 비언어성 지능, 반응속도와의 상관 관계가 어떠한지 알아보고자 하였다. 방법: 본 연구참여자는 5 세 일반 아동 16 명, 6 세 일반 아동 17 명, 총 33 명으로 하였다. 그림상징 크 기와 수에 따른 5 가지의 $\mathrm{AAC}$ 보드를 개발하여 검사자가 말한 그림상징을 선택하게 하여 그 반응속도를 측정하였다. AAC 보드 유형에 따른 집단 간 반응속도의 차이를 검증하기 위해 혼합분산분석을 실시하였으며, 연령, 어휘능력, 비언어적 지능과 그림상징 선택 반응속 도와의 상관관계를 살펴보았다. 결과: 5 세와 6 세 집단 간 그림상징 선택 반응속도의 주효과가 유의하였고, 그림상징의 크기와 수에 따 른 의사소통 보드 유형에서도 반응속도의 차이가 유의한 것으로 나타났다. 각 변인과의 상관관계를 분석한 결과 연령, 수용어휘능력, 비언어성 지능이 그림상징 크기와수에 따라서 유의한 상관관계를 보이는 것으로 나타났다. 논의 및 결론: $\mathrm{AAC}$ 사용자의 연령, 어휘능 력, 및 지능에 따른 $\mathrm{AAC}$ 보드 유형을 고려하여 제작 및 제공의 필요성에 대해 논의하였다.

핵심어: 보완대체 의사소통, 그림상징, 크기와 수, 반응속도

이 논문은 제1저자의 석사학위 논문을 수정·보완한 것임.

이논문은 인하대학교의 지원에 의하여 연구되었음.

\section{참고문헌}

강민지, 임경열, 이현정 (2018). 감정 어휘 상징 유형에 따른 상징 선택의 정확도 및 선호도. 언어치료연구, 27(4), 55-60.

강로원, 김영태, 연석정 (2019). 한국 대학생과 미국 대학생의 AAC 사회어 그림 상징 인식에 대한 문화적 차이. Communication Sciences \& Disor-

ders, 24(1), 71-86.

김영태 (2014). 말-언어장애 아동을 위한 보완·대체 의사소통(AAC) 활용을 위한 탐색. 보완대체의사소통연구, 2(1), 1-22.

김영태, 홍경훈, 김경희, 장혜성, 이주연 (2009). 수용 - 표현어휘력 검사(REVT). 서울: 서울장애인종합복지관.

김정연, 박은혜, 김경양 (2010). 음성산출 의사소통 콘텐츠 및 시스템 개발 기초연구: AAC 관련전문가의 경험 및 요구분석을 중심으로. 특수교육 저

널: 이론과 실천, 11(4), 345-374.

박은혜 (2000). 보완 · 대체의사소통 사용자의 언어발달. 언어청각장애연구, 5(1), 5-32.

박은혜, 김영태, 홍기형, 연석정, 김경양 임장현 (2016). 이화-AAC 상징체계 개발 연구: 어휘 및 그래픽 상징의 타당성. 보완대체의사소통연구, 4(2),

$19-40$.

박혜원 (2014). 한국비언어지능검사 2판(K CTONI-2). 서울: 마인드프레스.

배소영, 곽금주 (2011). 맥아더-베이츠 의사소통발달 평가(K M-B CDI). 서울: 마인드프레스.

송기범, 최양규 (2012). 동작어휘 상징의 애니메이션 효과성 검증 연구-성인, 아동, 지적장애아동을 중심으로. 지적장애연구, 14(4), 293-310.

신상은 (2017). 고정배열된 AAC 그림상징이 문장구성에 미치는 효과. Communication Sciences \& Disorders, 23(2), 341-351.

신상은 (2018). AAC 그림상징에 대한 판별과 선택 수행능력 간의 관계. 보완대체의사소통연구, 6(2), 45-61.

신상은, 김영태, 박은혜 (2017). AAC 그림상징 판별에 관한 연구: 명사, 부사, 동사를 중심으로. Communication Sciences \& Disorders, 22(3), 597-

607. 
연석정, 김영태, 박은혜 (2016). 이화-AAC 상징체계의 상징투명도와 명명일치도 특성 비교연구: 명사, 동사, 형용사를 중심으로. 보완대체의사소통연 구, 4(1), 45-63.

이경숙, 박창일, 김향희, 박은숙 (2004). 3, 4, 5 및 6세 아동의 생성이름대기 능력의 발달. 언어청각장애연구, 9(3), 1-21.

이유경, 이현정, 김영태, 연석정 (2015). 태블릿 PC 기반 보완대체의사소통의 어휘 선택 경로가 일반아동과 지적장애아동의 AAC 어휘표현 정확도 및 선호도에 미치는 영향. Communication Sciences \& Disorders, 20(2), 344-353.

이효주, 박현주 (2016). 그림상징 유형에 따른 학령전기 아동의 개념이해 및 선호도. 보완대체의사소통연구, 4(1), 65-82.

채수정, 박경옥, 김경양, 연석정 (2020). 중도 비구어장애인을 위한 AAC 어휘 및 그림상징 개발: 인권, 피해, 지역사회 의사소통 상황을 중심으로. 지체

중복건강장애연구, 63(2), 119-140.

최양규, 송기범 (2010a). 애니메이션 효과가 정서 그림 상징의 식별에 미치는 영향. 언어치료연구, 19(2), 163-178.

최양규, 송기범 (2010b). 그림의 사실성과 색상 및 의미 유형이 상징 식별에 미치는 영향. 특수교육 저널 이론과 실천, 11(2), 387-399.

\section{ORCID}

홍서아(제1저자, 대학원생 https://orcid.org/0000-0002-5609-331X); 연석정(교신저자, 조교수 https://orcid.org/0000-0001-5226-9624) 